\title{
Role of myometrial activity in sperm transport through the genital tract and in fertilization in sows
}

\author{
P. Langendijk¹, E. G. Bouwman ${ }^{1}$, A. Kidson², R. N. Kirkwood ${ }^{3}$, \\ N. M. Soede ${ }^{1}$ and B. Kemp ${ }^{1}$ \\ ${ }^{1}$ Department of Animal Sciences, Wageningen University, PO Box 338, $6700 \mathrm{AH}$ \\ Wageningen, The Netherlands; ${ }^{2}$ Faculty of Veterinary Medicine, Department of Farm Animal \\ Health, University of Utrecht, Yalelaan 7, Utrecht, The Netherlands; and ${ }^{3}$ Department for \\ Large Animal Clinical Sciences, Michigan State University, East Lansing, MI, USA
}

The effects of stimulation and suppression of uterine contractility at about the time of insemination on sperm distribution and fertilization in multiparous sows are described. For assessment of fertilization, sows were inseminated about $28 \mathrm{~h}$ before (synchronized) ovulation and killed at day 5 after ovulation $(n=53)$. For assessment of sperm distribution, sows were inseminated about $20 \mathrm{~h}$ before expected ovulation and were killed $12 \mathrm{~h}$ later $(n=26)$. At $10 \mathrm{~min}$ before insemination, sows received an intrauterine infusion of one of three solutions: (i) saline (control); (ii) $0.60 \mathrm{mg}$ clenbuterol hydrochloride to suppress contractility; or (iii) $1 \mathrm{mg}$ cloprostenol to stimulate contractility. Both clenbuterol and cloprostenol reduced median fertilization rate $(P<0.05)$ and median number of accessory sperm cells $(P<0.05)$. Distribution of sperm cells was also affected by treatments. Clenbuterol increased, and cloprostenol decreased, the number of sperm cells $(P<0.05)$ in the proximal $20 \mathrm{~cm}$ of the uterine horn and in the uterotubal junction. In addition, clenbuterol tended to increase and cloprostenol tended to decrease the number of sperm cells in the isthmus, although these effects were not significant. However, relative to the number of sperm cells in the uterus, clenbuterol treatment reduced the number of sperm cells in the uterotubal junction and oviduct, in contrast to cloprostenol. Cloprostenol increased the reflux of semen during insemination. It is hypothesized that suppression of uterine contractility increases transuterine transport time, reducing the ability of sperm cells to enter the uterotubal junction and the oviduct. Stimulation of uterine contractility above a certain level probably increases reflux and impedes transuterine transport of sufficient numbers of sperm cells.

\section{Introduction}

In pigs, sperm cells have to be transported from the cervical end to the tubal end of the uterine horns after mating or artificial insemination. The length of the uterine horns is about $0.8 \mathrm{~m}$ during oestrus (Palmer et al., 1965) and the transport of semen through the horns is probably a passive process. This passive transport is probably driven by the flow of intrauterine fluid containing sperm cells, due to gravitational force, movement of the sow and uterine contractions (Scott, 2000). The uterine lumen is a relatively hostile environment for the sperm cells and uterine contractions are probably important for transportation of sperm cells to the uterotubal junction as soon as possible after insemination. The uterotubal junction and the first part of the isthmus serve as a barrier for sperm cells and act as a sperm reservoir until the time of ovulation, when the ascent of sperm cells from the reservoir into the oviduct is increased (Hunter, 1981). Stimulation of uterine contractility accelerates the transport of sperm cells to the sperm reservoir, thereby increasing the number of sperm cells

Email: pieter.langendijk@genr.vh.wau.nl surviving until the time of fertilization. However, there is almost no evidence for the effect of increased uterine contractility on distribution of sperm cells through the genital tract and on fertilization (Stratman et al., 1959; Baker et al., 1968). Furthermore, there is no literature available concerning the question of whether uterine contractility is even necessary for transport of sperm cells and fertilization.

Recent research has demonstrated that clenbuterol can act as a suppressor, and cloprostenol as a stimulator, of uterine contractility during oestrus (Langendijk et al., in press). The aim of the present study was to investigate the effects of clenbuterol and cloprostenol at about the time of insemination on the distribution of sperm cells throughout the genital tract, and on fertilization.

\section{Materials and Methods}

\section{Animals and housing}

Experiments were approved by the Ethical Committee for animal experiments of Wageningen University. On the day of weaning (day 0), multiparous sows (third to sixth parity) of a commercial breed (Landrace $\times$ Yorkshire) were 
transported to the experimental farm in batches of 18 sows. The mean $( \pm \mathrm{SD}$ ) lactational period was $21.0 \pm 3.4$ days, mean litter size was $9.8 \pm 1.3$ and the sows weighed $235.0 \pm 15.4 \mathrm{~kg}$ at weaning. The sows were housed in individual crates and fed twice a day, at 08:30 $\mathrm{h}$ and $16: 30 \mathrm{~h}$, receiving $2.5 \mathrm{~kg}$ per day of a standard gestation diet $\left(12.9 \mathrm{MJ}\right.$ metabolizable energy $\mathrm{kg}^{-1}, 130 \mathrm{~g}$ crude protein $\mathrm{kg}^{-1}$ ). At $83-87 \mathrm{~h}$ after weaning, the sows were treated i.m. with $50 \mu \mathrm{g}$ GnRH (Depherelin ${ }^{\circledR}$; Veyx-Pharma, Schwarzenborn), to synchronize ovulation. Preliminary work (Langendijk et al., 2000) showed that in sows treated with $\mathrm{GnRH}$ at $87 \mathrm{~h}$ after weaning, ovulation occurred $38 \mathrm{~h}$ (range 35-41 h) after GnRH administration. Per batch, 12 sows were used for recovery of embryos and unfertilized oocytes at day 5 after ovulation, and six sows were used for recovery of sperm cells after insemination.

\section{Treatments}

Sows were assigned to one of three treatments, with parities and body weights distributed equally among the treatments. For recovery of embryos and oocytes, sows were inseminated $28 \mathrm{~h}$ before expected ovulation, with $5.0 \times 10^{8}$ sperm cells in $40 \mathrm{ml}$. Timing and dose were chosen to achieve intermediate fertilization rates for the control treatment. For recovery of sperm cells, sows were inseminated $20 \mathrm{~h}$ before expected ovulation, with $3.0 \times 10^{9}$ sperm cells in $40 \mathrm{ml}$. Time and dose in this case were chosen to achieve quantifiable numbers of sperm cells in the genital tract. Semen was obtained from 20 different boars, distributing the boars equally among the three treatments. Insemination was performed with a 'hands free' method, using regular Spirettes (Minitub, Tiefenbach), with a $40 \mathrm{~cm}$ tube connecting the spirette to the semen container. The semen container was always fixed at the same height (about $25 \mathrm{~cm}$ ) relative to the sow's back, to ensure that gravitational pressure was constant for all sows. Depending on the treatment, the sows were infused with one of the following solutions at $10 \mathrm{~min}$ before insemination: (i) $1 \mathrm{mg}$ cloprostenol (Estrumate; Schering-Plough, Maarssen) in $40 \mathrm{ml}$ saline, to stimulate uterine contractility; (ii) $0.60 \mathrm{mg}$ clenbuterol hydrochloride (Planipart; Boehringer-Ingelheim, Alkmaar) in $40 \mathrm{ml}$ saline, to suppress uterine contractility; or (iii) $40 \mathrm{ml}$ saline (control). In a previous study (Langendijk et al., in press), cloprostenol increased the frequency of uterine contractions from $11 \mathrm{~h}^{-1}$ to $22 \mathrm{~h}^{-1}$, and clenbuterol reduced the frequency of contractions from $18 \mathrm{~h}^{-1}$ to $6 \mathrm{~h}^{-1}$. The solutions were infused in the same way as described for the semen. Time needed to infuse the solutions and to infuse the semen dosages were both recorded. Reflux of semen during insemination was recorded on a subjective scale as no reflux, little reflux (up to about $5 \mathrm{ml}$ ) or much reflux $(>5 \mathrm{ml})$. After infusion of the semen, $10 \mathrm{ml}$ Beltsville thawing solution (BTS) was infused to ensure that no sperm cells remained in the semen container and in the insemination pipette.

\section{Oestrus and ovulation}

Detection of oestrus was performed using a mature teaser boar. On days 0, 1 and 2, the sows were exposed to the boar once a day. Starting on day 3, detection of oestrus was performed at 06:00, 14:00 and 22:00 h until behavioural oestrus had ceased. The timing of detection of oestrus was chosen to avoid contact with the boar at about the time of insemination, which was 10:30 h (for later embryo recovery) or 18:30 h (for later sperm cell recovery). Oestrus was considered as the period during which the sows showed a standing response in reaction to the presence of a boar in combination with manual stimulation of the back and the flanks. Onset of oestrus was defined as $4 \mathrm{~h}$ before the first time a standing response was observed. End of oestrus was defined as $4 \mathrm{~h}$ after the last time a standing response was observed.

Transrectal ultrasonography was performed using a 7.5 MHz annular array sector probe (Pie Medical, Maastricht), according to the method of Soede et al. (1992). Ultrasonography was performed on day 0 to detect pigs with corpora lutea on the ovaries (indicating lactational oestrus) or follicles $>5 \mathrm{~mm}$ in diameter (indicating premature oestrus), and on day 3 to assess follicular development in the other pigs. Only sows not showing lactational oestrus, premature oestrus or lack of follicular development on day 3 were used for the experiments. On day 5, ultrasonography was performed at 06:30, 10:30, 14:30, 18:30 and 22:30 $\mathrm{h}$ to detect the timing of ovulation for the sows in which fertilization rate was assessed. Time of ovulation was defined as the time between the last time that preovulatory follicles were detected and the first time that no follicles could be detected on the ovary.

\section{Embryonic development}

For recovery of embryos and unfertilized oocytes, the sows were killed at $113 \mathrm{~h}(109-117 \mathrm{~h})$ after ovulation. Collection of the embryos and the oocytes, morphological assessment and further processing and staining for the counting of embryonic nuclei and accessory spermatozoa were performed as described by Steverink et al. (1998). An oocyte was classified as unfertilized if the number of nuclei was zero or one. Embryos in which most of the nuclei were degenerated were classified as degenerated. This occurred only in embryos with fewer than 20 nuclei. The remaining embryos were considered normal. Recovery rate per sow was calculated as the percentage of embryos and oocytes recovered, on the basis of the number of corpora lutea. Fertilization rate was calculated as the percentage of normal and degenerated embryos relative to the total number of recovered embryos and oocytes per sow. Number of cell cycles, as a measure of embryonic development, was calculated as the base-2 logarithm of the number of counted nuclei of the embryos. The number of accessory sperm cells in the zona pellucida of the embryos, as a measure of the number of spermatozoa present at about the time of fertilization, was expressed as the average per sow. 


\section{Sperm recovery}

For the recovery of sperm cells from the genital tract, the spermatozoa used for insemination were labelled with Hoechst 33342 (an epifluorescent, non-lethal dye), by adding $200 \mu \mathrm{l}$ of a $2 \mathrm{mmol} \mathrm{I}^{-1}$ stock solution to each semen dose at $1 \mathrm{~h}$ before insemination. About $8 \mathrm{~h}$ before expected ovulation (12 h after insemination), the sows were killed for recovery of sperm cells. Immediately after stunning and exsanguination, the genital tract was removed by abdominal incision, avoiding manipulation of the tract as much as possible, and spread out on a flat surface. The following sections were separated from the rest of the genital tract: the proximal (tubal end) $20 \mathrm{~cm}$ of the uterine horns, $1 \mathrm{~cm}$ proximal to $1 \mathrm{~cm}$ distal from the uterotubal junction, the distal half of the oviduct (isthmus), and the proximal half of the oviduct (ampulla). The proximal $20 \mathrm{~cm}$ of the uterine horns was flushed twice with $20 \mathrm{ml}$ Dulbecco's PBS (DPBS). The isthmus and ampulla were flushed with $5 \mathrm{ml}$ DPBS in a uterine direction. The uterotubal junction was filled with $1 \mathrm{ml}$ DPBS, massaged, emptied and flushed with $5 \mathrm{ml}$ DPBS in a uterine direction. The uterotubal junction was cut open along the longitudinal axis, turned inside out and rinsed in $5 \mathrm{ml}$ DPBS. All fluids were pooled per segment and centrifuged at $1500 \mathrm{~g}$ for $5 \mathrm{~min}$ to concentrate the sperm. Sperm cell concentration in the samples was determined in duplicate, using a Bürker counting chamber. Sperm cells were counted in all the squares of the grid in a counting chamber. The flushed uterotubal junction, isthmus and ampulla sections were stored at $-20^{\circ} \mathrm{C}$ until further processing.

After thawing, the uterotubal junction, isthmus and ampulla were homogenized using small surgical scissors. During homogenization, the tissue was flushed regularly over a $100 \mu \mathrm{m}$ polyamide sieve with DPBS up to a volume mounting of about $30 \mathrm{ml}$. After thorough homogenization, the tissue was suspended in $5 \mathrm{ml}$ DPBS, vortexed and flushed again over the sieve with $5 \mathrm{ml}$ DPBS. The suspending and flushing was repeated. The resulting filtrate (about $50 \mathrm{ml}$ ) was concentrated to about $5 \mathrm{ml}$ by centrifugation at $1500 \mathrm{~g}$ for $5 \mathrm{~min}$. Counting of sperm cells was performed using a Bürker counting chamber, under a fluorescence microscope (Zeiss, $\times 200$, UV filter). The numbers of recovered sperm cells obtained by the different procedures were added up per genital tract section: the proximal uterine horn, the uterotubal junction, the isthmus and the ampulla. In addition, the number of sperm cells in the entire oviduct was calculated as the sum of the numbers in the isthmus and in the ampulla. In a preliminary trial, when live sperm cells were infused in freshly obtained oviducts in quantifiable amounts $\left(1.0 \times 10^{4}\right.$ to $5.0 \times 10^{4}$ ), incubated at $37^{\circ} \mathrm{C}$ for about $1 \mathrm{~h}$ and then frozen, this procedure resulted in recovery of approximately $80 \%$ of the infused sperm cells.

\section{Statistical analyses}

Data were analysed using SAS (SAS Institute Inc., Cary, NC). Effects of treatments on onset of oestrus, duration of oestrus, timing of ovulation, number of embryonic nuclei and on the difference between hormone and semen infusion times within sows were analysed by ANOVA using the following model: $Y_{\mathrm{ij}}=\mu+T_{\mathrm{i}}+e_{\mathrm{j}}$, with $T$ being the different treatments. Effects of treatments on fertilization rate, number of accessory sperm cells, number of sperm cells in the different parts of the genital tract, and time needed for infusion of hormone and semen were analysed using Wilcoxon rank scores in the NPAR1WAY procedure. Correlations between, for example, uterine horn length and number of sperm cells were analysed with ANOVA after log transformation of the number of sperm cells. Chi-squared analysis was used to assess relationships among class variables.

\section{Results}

\section{Sperm cell distribution}

Oestrus. Nineteen of the 26 sows showed behavioural oestrus before they were killed for recovery of sperm cells. Nevertheless, all the 26 sows were mated. All sows showing oestrus were in oestrus before or at the time of insemination: the interval from the onset of oestrus to insemination was $12 \pm 2 \mathrm{~h}(0-31 \mathrm{~h})$ on average. The onset of oestrus (91 $\pm 2 \mathrm{~h}$ after weaning) was not affected by the treatments. The timing of onset of oestrus was not related to the number of sperm cells recovered. The number of sperm cells recovered from sows that did not display oestrus by the time they were killed was not different from that of other sows. Therefore, data from all 26 sows were pooled.

Recovery of sperm cells. The number of sperm cells counted in the flushings and homogenized samples of the isthmi and ampullae was low; for about $90 \%$ of the samples, the number of sperm cells counted in the entire grid of the Bürker counting chamber was $<10$. In the uterotubal junction and uterine horn, the number of sperm cells ranged between 0 and 200 per chamber. No sperm cells were recovered in four of 26 (ampulla), four of 26 (isthmus), 0 of 26 (uterotubal junction) and one of 26 (uterine horn) sows. The number of recovered sperm cells was skewed and varied greatly among sows (Table 1). Most sperm cells were recovered from the uterotubal junction and the uterine horn (both about 50\%), and a small percentage of the sperm cells recovered originated from the oviduct $(<1 \%)$.

Effect of treatments. The median number of sperm cells recovered from the different sections of the genital tract was 3549 for the ampulla, 2602 for the isthmus, 557651 for the uterotubal junction, and 290521 for the proximal uterine horn (Tables 1 and 2). The number of sperm cells in the isthmus tended to be higher in pigs that received clenbuterol treatment, compared with the cloprostenol treatment, although this difference was not significant. In the uterotubal junction and the uterine horn, the number of 
Table 1. Number of sperm cells $(\times 1000)$ recovered from the different parts of the genital tract of sows $12 \mathrm{~h}$ after insemination with $3 \times 10^{9}$ sperm cells, by flushing and by homogenizing the flushed tissue

\begin{tabular}{|c|c|c|c|c|c|c|}
\hline \multirow[b]{2}{*}{ Sample } & \multirow[b]{2}{*}{ Treatment } & \multirow[b]{2}{*}{$n$} & \multicolumn{2}{|c|}{$\begin{array}{l}\text { Recovery per sow } \\
\quad(\times 1000)\end{array}$} & \multirow{2}{*}{$\begin{array}{l}\text { Sows with } \\
\text { no recovery }\end{array}$} & \multirow{2}{*}{$\begin{array}{c}\text { Number of } \\
\text { sperm cells } \\
\text { represented } \\
\text { by each sperm } \\
\text { cell counted } \\
\text { in cytometer* }\end{array}$} \\
\hline & & & Median & Range & & \\
\hline \multirow[t]{2}{*}{ Ampulla } & Flushing & 26 & 0.1 & $0-6$ & 9 & 186 \\
\hline & Homogenate & 26 & 1.9 & 0-90 & 6 & 2408 \\
\hline \multirow[t]{2}{*}{ Isthmus } & Flushing & 26 & 0.4 & $0-17$ & 5 & 150 \\
\hline & Homogenate & 26 & 1.9 & 0-14 & 7 & 870 \\
\hline \multirow{2}{*}{$\begin{array}{l}\text { Uterotubal } \\
\text { junction }\end{array}$} & Flushing & 26 & 333 & $1.4-1885$ & 0 & 4000 \\
\hline & Homogenate & 26 & 46 & $2.7-552$ & 0 & 864 \\
\hline Uterine horn & Flushing & 26 & 331 & 0-19 210 & 1 & 21172 \\
\hline
\end{tabular}

*This figure has to be multiplied by the number of sperm cells counted in the cytometer to achieve the total number of sperm cells in a sample. Differences between rows are due to different sample volumes and due to centrifugation steps in some samples to increase sperm concentration. Sperm cells were counted in the whole grid of the Bürker counting chamber, unless concentration was sufficient to count 100 sperm cells within a smaller area of the grid.

Table 2. Number of sperm cells $(\times 1000)$ recovered from the different parts of the genital tract of sows after intrauterine infusion with clenbuterol, saline (control) or cloprostenol at $10 \mathrm{~min}$ before insemination

\begin{tabular}{|c|c|c|c|c|c|c|}
\hline \multirow[b]{2}{*}{ Segment } & \multicolumn{2}{|c|}{ Clenbuterol $(n=9)$} & \multicolumn{2}{|c|}{ Control $(n=9)$} & \multicolumn{2}{|c|}{ Cloprostenol $(n=8)$} \\
\hline & Median & Range & Median & Range & Median & Range \\
\hline \multicolumn{7}{|l|}{$\begin{array}{l}\text { Absolute numbers of } \\
\text { sperm cells }(\times 1000)\end{array}$} \\
\hline Ampulla & 2.6 & 0-91 & 3.5 & $0-20$ & 2.3 & $0-7$ \\
\hline Isthmus & $3.2^{x}$ & $0.4-10$ & $2.6^{x, y}$ & $0-23$ & $1.0^{y}$ & $0.1-14$ \\
\hline Oviduct* & 7.0 & $1.5-101$ & 10.6 & $0-27$ & 4.7 & 0-19 \\
\hline Uterotubal junction & $896^{a}$ & $147-2250$ & $558^{a}$ & $18-1565$ & $78^{\mathrm{b}}$ & 9-2065 \\
\hline Uterine horn & $1598^{\mathrm{a}}$ & 252-19 210 & $291^{\mathrm{a}}$ & 3-9088 & $41^{b}$ & $0-1334$ \\
\hline \multicolumn{7}{|l|}{$\begin{array}{c}\text { Numbers of sperm cells } \\
\text { relative to uterus }(\%)^{+}\end{array}$} \\
\hline Ampulla & 0.1 & 0-28 & 0.4 & $0-7$ & 2.3 & 0-193 \\
\hline Isthmus & 0.2 & $0.01-3$ & 0.3 & $0-8$ & 0.5 & $0-24$ \\
\hline Oviduct & $0.4^{x}$ & $0.02-31$ & $0.6^{x}$ & $0-8$ & $8.0^{y}$ & $0.3-193$ \\
\hline Uterotubal junction & $43^{\mathrm{a}}$ & $7.5-368$ & $134^{\mathrm{b}}$ & $3-1743$ & $201^{b}$ & $7.1-932$ \\
\hline
\end{tabular}

Figures are expressed absolutely and as a percentage of the number recovered from the uterine horn.

*Oviduct value is sum of isthmus and ampulla.

${ }^{\dagger}$ Number of sperm cells expressed as a percentage of those recovered from the uterus.

abValues with different superscripts indicate significant differences $(P<0.05)$ between treatments

xy Values with different superscripts tend towards significant differences $(P<0.10)$ between treatments.

sperm cells was higher for the clenbuterol and control treatments $(P<0.05)$ compared with the cloprostenol treatment. When numbers of sperm cells in the oviductal segments and the uterotubal junction were expressed relative to the number in the proximal part of the uterine horns, the treatments had an opposite effect. Per 100 sperm cells in the proximal uterine horns, 43 sperm cells were recovered from the uterotubal junction for the clenbuterol treatment compared with 134 and 201 sperm cells $(P<0.05)$ for the control and cloprostenol treatments, respectively. Similarly, per 100 sperm cells in the horns, 0.4 sperm cells were recovered from the oviduct for the clenbuterol treatment compared with eight sperm cells for the cloprostenol treatment.

The length of the uterine horns was dependent on the parity of the sows $(P<0.05)$; for third, fourth, fifth and sixth 
parity sows, the mean horn length was $59 \pm 6,63 \pm 8$, $76 \pm 5$ and $86 \pm 4 \mathrm{~cm}$, respectively. The length of the uterine horn was not related to the number of sperm cells recovered. There was no consistent difference between the number of sperm cells recovered from the left and right sides of the genital tract, but the number of sperm cells varied considerably between both sides. The average difference between the two sides was $39,47,48$ and $60 \%$ of the total number of sperm cells recovered from the uterine horn, uterotubal junction, isthmus and ampulla, respectively. The difference ranged from $0 \%$ to $100 \%$ for all four segments. The difference between horns was not affected by treatments, reflux or duration of insemination. In addition, the difference between horns was not affected by the difference in number of preovulatory follicles on the ovaries.

Duration of insemination and reflux of semen. The time needed to infuse the $40 \mathrm{ml}$ of treatment solution varied greatly between sows, and tended to be shorter for the clenbuterol treatment: median times were $25 \mathrm{~s}$ (7-60 s), $58 \mathrm{~s}(15-115 \mathrm{~s})$ and $64 \mathrm{~s}(14-240 \mathrm{~s})$ for the clenbuterol, control and cloprostenol treatments, respectively. The time needed for infusion of the semen dose did not differ between treatments: median times were $21 \mathrm{~s}(10-63 \mathrm{~s}), 58 \mathrm{~s}$ (20-100 s) and $59 \mathrm{~s}(10-675 \mathrm{~s})$ for clenbuterol, control and cloprostenol treatments, respectively. Within sows, the time needed for infusion of the semen was equal to the time needed to infuse the hormone for the control and the clenbuterol groups. In contrast, cloprostenol increased the time needed for insemination (+ 46 s on average), although the effect was not significant. During insemination, hardly any reflux was recorded; high reflux was recorded in only four of 26 sows, distributed evenly among treatments.

\section{Fertilization}

Oestrus and ovulation. For 55 of the 60 sows used for embryo recovery, ovulation took place 40 h (34-46 h) after $\mathrm{GnRH}$ injection. Four sows had ovulated before the first time that ultrasonography was performed, and one sow did not ovulate. Two sows were found to have only one uterine horn at death. Further analyses were based on the remaining 53 sows. Forty-five of the 53 sows showed behavioural oestrus. The sows showing oestrus came into oestrus between $25 \mathrm{~h}$ before and $23 \mathrm{~h}$ after insemination; the interval from the onset of oestrus to insemination was $5 \pm 2 \mathrm{~h}$. The interval from weaning to oestrus $(91 \pm 2 \mathrm{~h})$, the duration of oestrus $(50 \pm 2 \mathrm{~h})$, and the timing of ovulation were not affected by the treatments.

Fertilization. The mean number of corpora lutea at day 5 after ovulation was $20.7 \pm 0.4$, and the average recovery of embryos and oocytes was $86 \%$ of the number of corpora lutea. The fertilization rate varied from $0 \%$ to $100 \%$, with $40 \%$ of the sows having a fertilization rate of $<20 \%$, and $32 \%$ of the sows having a fertilization rate of $>80 \%$ (Fig. 1 ).

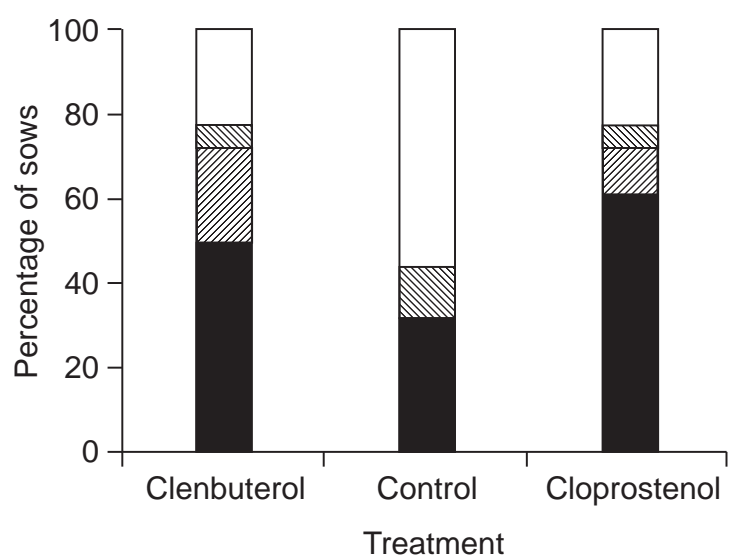

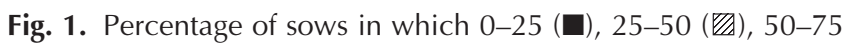
$(\mathbb{\nabla})$ or $75-100 \%(\square)$ of oocytes were fertilized after intrauterine infusion with clenbuterol $(n=18)$, saline (control; $n=16$ ) or cloprostenol $(n=19)$ at $10 \mathrm{~min}$ before insemination.

Degenerated embryos were observed in 18 of 53 sows. In these sows, 1.7 (1-4) degenerated embryos were observed on average. Fertilization rate was reduced $(P<0.05)$ by both the clenbuterol and the cloprostenol treatments compared with the control treatments (Table 3). The median number of accessory sperm cells (those associated with the zona pellucida) was also decreased by the two treatments $(P<0.05)$; the number of sperm cells was 2.1 per embryo for the control group versus 0.6 and 0.8 per normal embryo for the clenbuterol and cloprostenol treatments, respectively (Table 3 ). The number of accessory sperm cells was related to the fertilization rate. When the sow average was $<2$ sperm cells per embryo, the fertilization rate varied between $0 \%$ and $100 \%$, whereas when the sow average was $\geqslant 2$ sperm cells per embryo, fertilization rate was $\geqslant 80 \%$. In the control group, there tended to be more sows with $>2$ sperm cells per embryo, although this was not significant. The mean number of nuclei per embryo and the number of cell cycles were not affected by treatments (Table 3). A higher fertilization rate was associated with a higher number of nuclei $(r=0.56 ; P<0.01)$.

Duration of insemination and reflux of semen. The time needed for infusion of the $40 \mathrm{ml}$ treatment solutions varied greatly between the sows inseminated for recovery of embryos, but did not differ between treatments: median time was $40 \mathrm{~s}(4-330 \mathrm{~s}), 30 \mathrm{~s}(5-210 \mathrm{~s})$ and $33 \mathrm{~s}(9-510 \mathrm{~s})$ for the clenbuterol, control and cloprostenol treatments, respectively. The time required to infuse the semen dose was lowest for the clenbuterol group and highest for the cloprostenol group $(P<0.05)$ : median time was $20 \mathrm{~s}$ $(5-210 \mathrm{~s}), 52 \mathrm{~s}(10-218 \mathrm{~s})$ and $97 \mathrm{~s}(12-375 \mathrm{~s})$ for the clenbuterol, control and cloprostenol treatments, respectively. Within sows, the time required to infuse the semen in control sows was equal to the time needed for infusion of the hormone. However, clenbuterol treatment decreased the time $(-23 \mathrm{~s})$ required to infuse the semen compared with 
Table 3. Fertilization and embryo parameters for sows after intrauterine infusion with clenbuterol ( $n=18)$, saline (control; $n=16)$ or cloprostenol $(n=19)$ before insemination

\begin{tabular}{lcccccccc}
\hline & \multicolumn{2}{c}{ Clenbuterol } & & \multicolumn{2}{c}{ Control } & & \multicolumn{2}{c}{ Cloprostenol } \\
\cline { 2 - 3 } & $\begin{array}{l}\text { Median or } \\
\text { mean } \pm \text { SD }\end{array}$ & Range & & $\begin{array}{c}\text { Median or } \\
\text { mean } \pm \text { SD }\end{array}$ & Range & & $\begin{array}{c}\text { Median or } \\
\text { mean } \pm \text { SD }\end{array}$ & Range \\
\hline Fertilization* & $26^{\mathrm{a}}$ & $0-100$ & & $81^{\mathrm{b}}$ & $0-100$ & $21^{\mathrm{a}}$ & $0-100$ \\
Accessory sperm cells* $^{\mathrm{N}}$ & $0.6^{\mathrm{a}}$ & $0-38$ & & $2.1^{\mathrm{b}}$ & $1-21$ & & $0.8^{\mathrm{a}}$ & $0-19$ \\
Number of nuclei & $27 \pm 13$ & $6-48$ & & $36 \pm 15$ & $15-61$ & & $28 \pm 14$ & $7-53$ \\
Cell cycles & $4.4 \pm 0.9$ & $2.4-5.5$ & & $4.9 \pm 0.7$ & $3.8-5.9$ & & $4.4 \pm 0.9$ & $2.5-5.7$ \\
\hline
\end{tabular}

*SD is not given for data presented as medians because distributions were skewed.

abValues with different superscripts are significantly different $(P<0.05)$.

Table 4. Number of sows in which either $0-50 \%$ or $50-100 \%$ of oocytes were fertilized in relation to the amount of backflow observed during insemination, after intrauterine infusion with clenbuterol, saline (control) or cloprostenol before insemination

\begin{tabular}{|c|c|c|c|c|c|c|c|c|}
\hline \multirow{2}{*}{$\begin{array}{l}\text { Amount of } \\
\text { backflow }\end{array}$} & \multicolumn{2}{|c|}{$\begin{array}{c}\text { Clenbuterol } \\
\text { fertilization (\%) }\end{array}$} & \multicolumn{2}{|c|}{$\begin{array}{c}\text { Control } \\
\text { fertilization (\%) }\end{array}$} & \multicolumn{2}{|c|}{$\begin{array}{c}\text { Cloprostenol } \\
\text { fertilization (\%) }\end{array}$} & \multicolumn{2}{|c|}{$\begin{array}{c}\text { Total* } \\
\text { fertilization (\%) }\end{array}$} \\
\hline & $\leqslant 50$ & $>50$ & $\leqslant 50$ & $>50$ & $\leqslant 50$ & $>50$ & $\leqslant 50$ & $>50$ \\
\hline None & 12 & 4 & 2 & 9 & 2 & 1 & 16 & 14 \\
\hline Small & 1 & 1 & 1 & 2 & 6 & 3 & 8 & 6 \\
\hline $\mathrm{High}^{+}$ & 0 & 0 & 2 & 0 & 5 & 1 & 7 & 1 \\
\hline
\end{tabular}

*A high amount of backflow was related to a fertilization rate $<50 \%$ (chi-squared analysis; $P<0.10$ ).

${ }^{+}$For the cloprostenol treatment, more sows had a high amount of backflow (chi-squared analysis; $P<0.05$ ).

the time required to infuse the hormone within sows. In contrast, cloprostenol treatment increased the time $(+29 \mathrm{~s})$ needed for infusion of the semen compared with the time needed for infusion of the hormone within sows. However, these differences between the treatments were not significant. Reflux of semen during insemination was increased by the cloprostenol treatment $(P<0.05)$ : six of the 18 cloprostenol-treated sows had high reflux, compared with none of 18 clenbuterol-treated sows, and two of the 16 control sows (Table 4). Furthermore, a high amount of reflux tended to be related to a poor fertilization rate: seven of eight $(88 \%)$ sows with a high amount of reflux had a fertilization rate $<50 \%$, whereas 24 of $44(55 \%)$ sows with little or no reflux had a fertilization rate $<50 \%$.

\section{Discussion}

For the control sows, the fertilization rate was in a normal range for sows inseminated with a low semen dose about $30 \mathrm{~h}$ before ovulation (Soede et al., 1995; Steverink et al., 1997). The timing of insemination and sperm cell dose $\left(5.0 \times 10^{8}\right)$ in the present study were chosen to achieve intermediate fertilization results. In that way, both positive and negative effects of treatment on fertilization rate could be detected. Both suppression and stimulation of uterine contractility adversely affected fertilization in the present study. Such a low fertilization rate is probably due to a decreased number of sperm cells present in the oviduct about the time of fertilization, which was reflected in the low number of accessory sperm cells in the two treatments $(P<0.05)$. Saacke $(1998)$ suggested that the number of accessory sperm cells could be regarded as a measure of the number of fertile sperm cells present at about the time of fertilization. Whether this is also true for pigs is not clear. Embryonic development was not affected by the treatments. The mean number of cell cycles was higher for the control treatment, but this was probably due to the higher fertilization rate in this group, as embryonic development correlates positively with fertilization rate (Kemp and Soede, 1997).

The number of sperm cells in the samples from the oviducts was low and, therefore, sperm cell count was less reliable in these samples. In addition, with the method applied, recovery of sperm cells from the oviducts varied at about $80 \%$ of the sperm cells. Both aspects probably contributed to the variation between samples of the oviducts. Nevertheless, the method applied in this study is an extension of methods described earlier by Mburu et al. (1996) and by Matthijs et al. (2000), and was regarded as suitable to study sperm transport through the genital tract.

Sperm transport to the site of fertilization is thought to be a combination of both passive and active transport. Passive transport is more important in the initial phase of sperm transport, this being from the site of deposition (cervix) to 
the proximal uterus and the uterotubal junction (Scott, 2000). The passive part of sperm transport is probably due to the flow of fluid caused by gravity and by contractile movement of the uterine horns, and requires a minimal volume (about $50 \mathrm{ml}$ ) of inseminate during artificial insemination (Baker et al., 1968). From the cervix the uterine horns progress downward into the abdominal cavity, and then upward again, towards the oviducts and ovaries. Contractile activity probably promotes distribution of sperm-containing fluids throughout the whole tract, even enabling unilaterally, deep intrauterine-deposited semen to be distributed over two horns (Rath, 2000).

The flow of the inseminate into the genital tract during insemination, the first part of passive transport, was fastest for the clenbuterol treatment and slowest for the cloprostenol treatment, on the basis of the duration of insemination. Suppression of contractility by clenbuterol treatment probably enabled flow of the semen due to gravitational force, without being obstructed by phasic contractions of the uterine horns. In contrast, stimulation of contractility by the cloprostenol treatment prolonged the time required for the semen to flow into the genital tract, probably because the uterine horns were obstructed periodically by contractions during insemination. In a previous study, cloprostenol treatment increased the frequency of contractions from $11 \mathrm{~h}^{-1}$ to $22 \mathrm{~h}^{-1}$, and the amplitude from $44 \mathrm{~mm} \mathrm{Hg}$ to $55 \mathrm{~mm} \mathrm{Hg}$ (Langendijk et al., in press). In the same study, a clenbuterol dose of $0.30 \mathrm{mg}$ reduced the frequency of contractions from $18 \mathrm{~h}^{-1}$ to $6 \mathrm{~h}^{-1}$, and the amplitude from $57 \mathrm{~mm} \mathrm{Hg}$ to $47 \mathrm{~mm} \mathrm{Hg}$. In the present study, reflux of semen was increased by the cloprostenol treatment. Uterine contractility was probably stimulated by cloprostenol to such an extent that uptake of semen by the uterine horns was impeded, thereby limiting the number of sperm cells reaching the proximal part of the uterine horn. This was confirmed both by the low fertilization rate and the low number of accessory sperm cells in sows killed at day 5 after insemination, and by the low number of sperm cells in the proximal uterus and uterotubal junction of sows killed on the day of insemination. Steverink et al. (1998) also found that a high amount of semen reflux during insemination with a low sperm dose $\left(<1 \times 10^{9}\right)$ resulted in reduced fertilization rates.

Active sperm transport, which is transport resulting from the intrinsic movement of sperm cells, is probably important for migration of sperm cells from the proximal uterus into the uterotubal junction and the oviduct. In the hours after insemination, the number of sperm cells in the uterine horns decreases rapidly, as a result of semen reflux, phagocytosis and transport into the oviducts. In this period, the number of sperm cells in the uterotubal junction and oviduct increases (First et al., 1968; Pursel et al., 1978; Viring, 1980). The uterotubal junction and the lower part of the isthmus are considered to be sperm reservoirs, acting as a storage place for sperm cells, until about the time of ovulation. The sperm reservoir forms a barrier to sperm cells, because of its morphology, the consistency of the luminal mucus, oviductal motility, sperm-epithelial adhesion and ciliary movements of oviductal cells (Rodriguez-Martinez, 2000). This barrier is selective, as it favours passage of live and motile sperm cells (Baker and Degen, 1972). At about the time of ovulation, changes in the uterotubal and oviductal environment occur, which promote the ascent of sperm cells towards the ampulla and the site of fertilization (Hunter, 1981).

For the clenbuterol treatment, the number of sperm cells in the different sections was equal to or higher than those for the control and cloprostenol treatments, respectively. Nevertheless, the fertilization rate, as well as the number of accessory sperm cells, was lower for clenbuterol compared with the control group, which seemingly contradicts the observed numbers of sperm cells in the oviducts and uterotubal junction. The use of $3 \times 10^{9}$ sperm cells in the sperm recovery study might have masked the real differences that were present in the oviduct in the fertilization study, in which $5.0 \times 10^{8}$ sperm cells were inseminated. Another possibility is that the sperm cells that reached the proximal end of the uterus in the clenbuterol treatment were less able to fertilize than were those in the control group. This possibility is supported by the fact that relative to the numbers recovered from the proximal part of the uterine horns, fewer sperm cells were recovered from the uterotubal junction and oviduct compared with the control and cloprostenol treatments, respectively. Apparently, for the clenbuterol treatment, the sperm cells were less able to pass through the uterotubal junction into the oviduct (active transport), and this might indicate that the fertilizing capacity of these sperm cells was also reduced. The capacity of the uterotubal junction and isthmus was not limiting because, for all treatments, the number of sperm cells in the uterotubal junction and isthmus was related linearly to the number in the proximal uterus, without reaching a plateau (data not shown). Moreover, other studies have found a higher number of sperm cells in the uterotubal junction and isthmus (First et al., 1968; Viring, 1980). This implies that the clenbuterol treatment either reduced the ability of the sperm cells to penetrate the uterotubal junction and the oviducts, or affected the environment of the uterotubal junction and the oviducts, rendering them less accessible to the passage of sperm cells, or both. The reduction of contractility by the clenbuterol treatment might have prolonged the time required to transport the sperm cells from the distal part to the proximal part of the uterine horns (passive transport). The lifespan of sperm cells is much shorter in uteri than in the oviducts (First, 1968; Scott, 2000). We hypothesize that the increased transport time to the proximal uterus reduced the ability of the sperm cells to penetrate the uterotubal junction and the oviducts, and the ability to fertilize. As well as affecting the intrinsic quality of the sperm cells by reducing transport time, uterine contractions may also play a role in the propulsion of sperm cells from the uterine horns into the oviducts. Baker and Degen (1972) observed a pulsatile appearance of fluid from the uterine horns into cannulated oviducts shortly after insemination. The reduction of contractility as a result of clenbuterol 
treatment might have reduced this passive transport into the uterotubal junction and isthmus. Accessibility of the oviducts might also have been affected by the clenbuterol treatment. As a $\beta$-adrenergic agonist, clenbuterol might have reduced oviductal contractility, probably relaxing the oviductal barrier. Alternatively, clenbuterol might have dilated blood capillaries around the uterotubal junction, thereby increasing swelling of the tissue of the uterotubal junction and reducing accessibility. Oviduct status was not recorded in the present study, but for these hypothesized effects of the treatments on the oviduct to occur, plasma concentrations of clenbuterol and cloprostenol should have been high enough until about the time of recovery of sperm cells. Cloprostenol has a relatively short half-life of about $2 \mathrm{~h}$ (information supplied by manufacturer), which would be too short to affect oviductal status at about the time of fertilization or at about the time of recovery of sperm cells. It is not clear whether plasma concentrations of clenbuterol at about the time of colonization of the sperm reservoirs was high enough to affect contractility of the uterus and the oviducts. Absorption of clenbuterol from the uterine horns, based on oral administration in other species (Smith, 1998), is probably complete within about $2 \mathrm{~h}$, indicating a fast decrease in the local concentration of clenbuterol around the uterus. However, the half-life of clenbuterol in plasma ranges from $9 \mathrm{~h}$ in rabbits to $30 \mathrm{~h}$ in humans (Yamamoto et al., 1985).

In conclusion, a minimum level of uterine contractility at about the time of insemination appears to be important for rapid transport of sperm cells to the tubal end of the uterine horns. A prolonged phase of transport through the uterine horns might adversely affect the ability of sperm cells to penetrate the uterotubal junction and the oviduct and fertilize. However, above a certain level, uterine contractility increases reflux of semen to such an extent that the number of sperm cells reaching the tubal end of the uterine horns is reduced. More studies are required to establish an optimal level of uterine contractility and to investigate the importance of the timing of uterine contractility relative to the moment of insemination.

This research was supported by Schering-Plough Animal Health and the Dutch Federation of Co-operative Swine artificial insemination centres. In addition, the authors would like to thank Christiaan Korpershoek and Wessel ten Haaf, the MSc students who put a lot of effort into the experimental work and data analyses.

\section{References}

Baker RD and Degen AA (1972) Transport of live and dead boar spermatozoa within the reproductive tract of gilts Journal of Reproduction and Fertility 28 369-377

Baker RD, Dziuk PJ and Norton HW (1968) Effect of volume of semen, number of sperm and drugs on transport of sperm in artificially inseminated gilts Journal of Animal Science 27 88-93

First NL, Short RE, Peters JB and Stratman FW (1968) Transport and loss of boar spermatozoa in the reproductive tract of the sow Journal of Animal Science 27 1037-1040

Hunter RHF (1981) Sperm transport and reservoirs in the pig oviduct in relation to the time of ovulation Journal of Reproduction and Fertility 63 109-117
Kemp B and Soede NM (1997) Consequences of variation in interval from insemination to ovulation on fertilization in pigs Journal of Reproduction and Fertility Supplement 52 79-89

Langendijk P, Soede NM, Bouwman EG and Kemp B (2000) Synchronization of ovulation with GnRH or hCG in weaned sows, without pretreatment with eCG Journal of Reproduction and Fertility Abstract Series 2635 (Abstract)

Langendijk P, Bouwman EG, Soede NM, Taverne MAM and Kemp B Myometrial activity around oestrus in sows: spontaneous activity and effects of estrogens, cloprostenol, seminal plasma and clenbuterol Theriogenology (in press)

Matthijs A, Hakze R, Postma A and Woelders H (2000) Leukocyte recruitment and phagocytosis of boar spermatozoa. In Boar Semen Preservation IV pp 35-41 Eds LA Johnson and HD Guthrie. Allen Press Inc., Lawrence

Mburu JN, Einarsson S, Lundeheim N and Rodriguez-Martinez H (1996) Distribution, number and membrane integrity of spermatozoa in the pig oviduct in relation to spontaneous ovulation Animal Reproduction Science 45 109-121

Palmer WM, Teague HS and Venzke WG (1965) Macroscopic observations on the reproductive tract of the sow during lactation and early postweaning Journal of Animal Science 24 541-545

Pursel VG, Schulman LL and Johnson LA (1978) Distribution and morphology of fresh and frozen-thawed sperm in the reproductive tract of gilts after artificial insemination Biology of Rproduction 19 69-76

Rath D (2000) New strategies to minimize the number of sperm for pig Al ESDAR Newsletter 57 (Abstract)

Rodriguez-Martinez H (2000) The oviduct of the pig: do intraluminal glycosaminoglycans play a role in tubal function? In Boar Semen Preservation IV pp 153-163 Eds LA Johnson and HD Guthrie. Allen Press Inc., Lawrence

Saacke RG, Dalton JC, Nadir S, Bame J and Nebel RL (1998) Spermatozoal characteristics important to sperm transport, fertilisation and early embryonic development. In Gametes: Development and Function pp 320-335 Eds A Lauria, F Gandolfi, G Enne and L Gianaroli. Serono Symposium, Milano

Scott MA (2000) A glimpse at sperm function in vivo: sperm transport and epithelial interaction in the female reproductive tract Animal Reproduction Science 60-61 337-348

Smith DJ (1998) The pharmacokinetics, metabolism, and tissue residues of $\beta$-adrenergic agonists in livestock Journal of Animal Science 76 173-194

Soede NM, Kemp B and Noordhuizen JPTM (1992) The duration of ovulation in pigs, studied by transrectal ultrasonography, is not related to early embryonic diversity Theriogenology 38 653-666

Soede NM, Wetzels CCH, Zondag W, de Koning MAI and Kemp B (1995) Effects of time of insemination relative to ovulation, as determined by ultrasonography, on fertilisation rate and accessory sperm count in sows Journal of Reproduction and Fertility 104 99-106

Steverink DWB, Soede NM, Bouwman EG and Kemp B (1997) Influence of insemination-ovulation interval and sperm cell dose on fertilisation in sows Journal of Reproduction and Fertility 111 165-171

Steverink DWB, Soede NM, Bouwman EG and Kemp B (1998) Semen backflow after insemination and its effect on fertilisation in sows Animal Reproduction Science 54 109-119

Stratman FW, Self HL and Smith VR (1959) The effect of oxytocin on the fertility in gilts artificially inseminated with a low sperm concentration and semen volume Journal of Animal Science 18 634-640

Viring S (1980) Distribution of live and dead spermatozoa in the genital tract of gilts at different times after insemination Acta Veterinaria Scandinavica 21 587-597

Yamamoto I, Iwata K and Nakashima M (1985) Pharmacokinetics of plasma and urine clenbuterol in man, rat, and rabbit Journal of PharmacobioDynamics 8 385-391

Received 16 July 2001.

First decision 3 September 2001.

Final revision received 18 December 2001.

Accepted 19 December 2001. 